\title{
Methodological Review of impact studies of airports: A qualitative and quantitative proposal for the Airport of Málaga-Costa del Sol
}

\section{Revisión metodológica de estudios de impacto de aeropuertos: una propuesta cualitativa y cuantitativa para el Aeropuerto de Málaga-Costa del Sol}

Lidia Caballero Galeote (iD, Universidad de Málaga, España lidiacaballero1985@gmail.com

Josefa García Mestanza (iD, Universidad de Málaga, España img@uma.es

\begin{abstract}
Airports have become fundamental axes of the economy of many countries. In Spain, the airports managed by Aena ${ }^{1}$ ended 2019 with more than 274.4 million passengers, which was $4.4 \%$ more than the previous year. They are not only important for tourism but also for other sectors that depend on imports and exports. For years, the impact measurements have included the IO tables, but we are now questioning whether they constitute the best measurement model. The research reveals that the main problem is the application of different methodologies used by airports and countries. For this reason, we propose a model to measure the economic impact of the Malaga-Costa del Sol Airport that incorporates the importance of the tourism. This study is conceived as a guide for studying the impacts of any airport around the world. The review reveals that the social accounting matrix with changes in the variables involved is the best available measurement model. The conclusions reflect that the qualitative point of view is necessary. This can provide data that, together with previous studies, will result in multidisciplinary research that will allow us to gain a much deeper understanding of these infrastructures. The conclusions have practical and theoretical implications for impact studies.
\end{abstract}

Keywords: quantitative model; qualitative; economic impact; airport; input-output; SAM.

\section{RESUMEN}

Los aeropuertos se han convertido en ejes fundamentales de la economía de muchos países. En España, los aeropuertos gestionados por Aena cerraron 2019 con más de 274,4 millones de pasajeros, un $4,4 \%$ más que el año anterior. No solo son importantes para el turismo sino también para otros sectores que dependen de las importaciones y exportaciones. Durante 
años las mediciones de impacto han incluido las tablas IO, pero en la actualidad nos preguntamos si es el mejor modelo de medición. La investigación muestra que el principal problema es la diversidad de metodologías utilizadas por aeropuertos y países. Por ello, se propone un modelo de medición del impacto económico del Aeropuerto de Málaga-Costa del Sol que incorpora la importancia del turismo. Este estudio se concibe como una guía para analizar los impactos de cualquier aeropuerto del mundo. La revisión revela que la matriz de contabilidad social con cambios en las variables involucradas es el mejor modelo de medición disponible. Las conclusiones reflejan que el punto de vista cualitativo es necesario. Esto puede aportar datos que, junto a los anteriores, darán como resultado una investigación multidisciplinar que nos permitirá conocer mucho más profundamente estas infraestructuras. Las conclusiones tienen implicaciones prácticas y teóricas para las investigaciones de impacto.

Palabras clave: modelo cuantitativo; cualitativo; impacto económico; aeropuerto; input-output; SAM.

\section{INTRODUCTION}

Airport infrastructures and associated services present an undeniable flow of implications that go beyond economic impacts. This is due to the fact that, airports are not only places where airplanes just land and take off but evolve into major business and implications that extend deep into the local territory (Freestone,2009). Hence the importance of analyzing in this article the adequacy of the models of measurement of the economic impact.

It is therefore essential to know about the impact of airports and even more in the last times in which they have been questioned. According to Shankin Alexandrovich (2007), an airport is or should be a company, but in some countries such as Spain an airport is a public infrastructure controlled by state bodies (Spanish Constitution, 1979). As cited by Heng \& Low (1990), airports create a solid structure of networks that end up impacting not only in the region where it is located but in its inhabitants.

The choice of the city is not an arbitrary decision; Málaga has just become a worldwide reference in the development of complementary infrastructure for this sector. In recent years, this city has expanded its offer of accommodation, leisure, culture, and restoration. Undoubtedly, tourism has been largely responsible for this phenomenon of specialization, which permeates the complementary industry and ends up affecting its own development.

In 2019, the airport received 19.9 million passengers of which almost $70 \%$ were tourists (Aena, 2020). This indicates that tourism is a fundamental sector for the airport. The economic impact of the airport is therefore strongly related to the tourism sector. In fact, we could talk about a relationship of dependence. Tourism is the most important sector in the city and the arrival of tourists is thanks to the airport. On the other hand, the airport receives those tourists because they want to come to the city. In fact, within a two-hour drive we can find two other airports that also belong to the network and yet do not have the same number of passengers. We can mention the Seville Airport with 7,544,473 passengers (Presentación -Aena, 2020) or the Granada-Jaén Airport with 1,251,926 passengers in 2019 (Presentación -Aena, 2020). Not 
only does the territory and its business fabric benefit from all of this, but also its residents. Tourism $^{2}$ is able to mobilize hundreds of millions of people from anywhere in the world. It is no longer limited to be considered a cause of wealth and a sign of unprecedented economic growth, but it also stands as a crucial element for the improvement of culture, knowledge, communication, and respect among citizens of different ethnicities and races. According to INE data, after the economic crisis, the results recorded by tourist activity in 2015 confirm that it was the fastest-growing sector of the Spanish economy. Since 2010 until now, tourism had become the main driver of the economy and the main source of employment (Exceltour, 2020). This is also a symbol of the growth that airports have experienced.

The orientation of the labor market towards the tertiary sector, especially to those branches or sectors of activity most closely linked to the tourism compels us to take further measures to point our growth model towards a consolidation of the sector. In the case of the city of Malaga, since 2015 (14,404,206 passengers) the development has been exponential. The increase in destinations and routes has also changed the profile of the tourist and with it the city is trying to abandon the concept of sun and beach tourism towards a cultural tourism (Cruz, E. et al., 2019). For the specific measurement of these infrastructures it is necessary to evaluate the convenience of using quantitative models (simplified economic, regional econometric, causal studies and structural equations, input-output, cost-benefit, social accounting matrix, general equilibrium or TSA) with qualitative.

This article aims to fill the gap on the different methodologies and elements used in impact studies. Although, as we will see, there are studies that use similar methodologies, the variables do not establish the same level of segregation and are concentrated in different areas such as employment or the regional economy. It is therefore important to highlight that if the tools are standardized, it allows comparisons among airports, regions and countries.

The goal of this research is to analyze and evaluate the different available models and to propose the most convenient one to measure the economic impact of airports. In order to properly address this aim, we establish these specific steps:

a. A) Define the types of economic impacts, both quantitative (direct, indirect and induced) as well as qualitative, of the Airport of Malaga-Costa del Sol.

b. B) Determination of the use and utility of different sources of bibliographic information, statistics, institutional and studies related to the segregation of impacts.

c. C) Compile the different economic impact measurement models that can be used at airports.

d. D) Show the advantages and disadvantages of the implementation of these models.

e. E) Define an economic impact measurement model at the provincial level of the city of Malaga that emphasizes the direction of economic flows.

2. Between 2005 and 2007, the international community led by the United Nations defined a new conceptual framework, establishing the concepts that would be part of the work, classifications, and indicators of any national Tourism Statistics System (RIET, 2008). It is clear from these recommendations that a tourist is a person who travels to the main destination different from his/her usual environment, for a duration of less than one year, for any main purpose (leisure, business or other personal reason) other than that of being employed by an entity resident in the country or place visited. 
f. F) Define a qualitative measurement model.

The achievement of these specific objectives has been completed through a series of operational aims consisting of collecting, investigating, contrasting, analyzing, unifying, graphing and interpreting information from various bibliographic, statistical, institutional and related studies. Taking into account the space-time context in which the present article is developed.

\section{THEORETICAL BACKGROUND}

An airport is defined as the area of land or water (including all buildings, facilities and equipment) destined wholly or partially for the arrival, departure and surface movements of aircraft (Enaire, 2016). The study of impact is not particularly new and it has been used for many years in different sectors and fields such as medicine (Moncada, 1999), environmental (Canter \& Wood, 1996), immigration (Liesner et al., 1971) or agriculture (Huag, 2014) among others. These infrastructures have also important implications for locals so their impacts need to be studied (Monterrubio, Andriotis \& Rodríguez-Muñoz, 2020). In this sense, several papers have analyzed the airports from different point of views.

Table 1. Airport impacts studies

\begin{tabular}{|c|l|}
\hline \multirow{5}{*}{ Economic } & $\begin{array}{l}\text { (Appold, 2015) (Augustyniak, 2009) (Butler \& Kiernan, 1986) (Basso, 2007) } \\
\text { (Diaz Olariaga \& Ávila Álvarez, 2015) (El-Fadel \& Chahine, 2002) (Fasone, Giuffrè } \\
\text { \& Maggiore, 2012) (Forsyth, 2006) (Gutiérrez et al., 1999) (Hanlon, 1995) } \\
\text { (Dimitriou, 2018) (Kuper, Massacci, Shim \& Williams, 2020) (Li and Loo, 2016) } \\
\text { (Mense \& Kholodilin, 2014) (Morimoto, 2019) (Pitfield, 1981) (Takebayashi, } \\
\text { 2011) (Tosun, 2002) (Qin \& Tian, 2019) }\end{array}$ \\
\hline Environmental & $\begin{array}{l}\text { (Chaouk, Pagliari \& Moxon, 2020) (El-Fadel \& Chahine, 2002) (Gratton, Padhra, } \\
\text { Rapsomanikis \& Williams, 2020) (J.Torija, 2018) (Maeda, 1991) (Mense } \\
\text { \& Kholodilin, 2014) (Ren, Cao \& Liu, 2018) (Sahrir, Bachok \& Osman, 2014) } \\
\text { (Zheng, Peng \& Hu, 2020) }\end{array}$ \\
\hline Social & $\begin{array}{l}\text { (Akehurst, 1999) (Alpes, 2015) (Bogicevic, Bujisic, Bilgihan, Yang \& Cobanoglu, } \\
\text { 2017) (Halpern, 2012) (Rowe \& Pitfield, 2018) (Pabedinskaité \& Akstinaité, } \\
\text { 2014) (Park \& Ryu, 2019) (Sahrir, Bachok \& Osman, 2014) (Tezel et al., 2019) } \\
\text { (Wilke, Majumdar \& Ochieng, 2015) }\end{array}$ \\
\hline Tourism & (Doerr, Dorn, Gaebler \& Potrafke, 2020) (Robbins \& Thompson, 2007) \\
\hline Technological & (Florido-Benítez, 2016) (Kidokoro \& Zhang, 2017) (Neumann, 2015) \\
\hline
\end{tabular}

Source: Compiled by author based on a WOS review.

One of the first impact studies about airports dates back to 1986 (Butler and Kiernan), although, years ago, (1978) Walters considered in his Airports - An Economic Survey the importance of airports not only on the territory but also on urban development, pollution, noise, and industrial activity. The report called Measuring the Regional Economic Significance of Airports (Butler \& Kiernan, 1986) provided advice on how to measure the importance of an airport in the economy. They argued that the economic impact of airports is the measure of 
the importance of aviation as industry taking into account the employment, goods and services that it consumes. This report was cancelled so it is not currently available (FAA, 2020).

In Europe, it was not until 1993 when the Economic Impact Study Kit was developed by Airports Council International. This is a wide measurement procedure in which it is attributed to the airport almost all of the activities comparing the economic results generated and recreating what would happen if it did not exist. In the case of airports located on islands, this model would apply a much higher impact to the reality, because the idiosyncrasy of their situation is only possible through air or sea (Gutiérrez et al., 1999). Although all of them analyze the economic perspective, not all of them focus on the impact from a general point of view. As can be seen in Table 2, research ranges from how deregulation or privatization affects the economy until what the cost of noise emissions are.

Table 2. Economic impact studies in relation to airports

\begin{tabular}{|c|c|c|c|c|c|c|}
\hline Authors & Year & Region & Model & Aim & \begin{tabular}{|c|}
$\begin{array}{c}\text { Variables or } \\
\text { elements } \\
\text { involved in the } \\
\text { research }\end{array}$ \\
\end{tabular} & Results \\
\hline Appold, S. & 2015 & United States & $\begin{array}{c}\text { Analysis of } \\
\text { Census } 2000 \\
\text { CTPP tract-level } \\
\text { data } \\
\end{array}$ & $\begin{array}{l}\text { Impact of } \\
\text { airports on } \\
\text { employment } \\
\text { and the benefits } \\
\end{array}$ & $\begin{array}{c}\text { Employment, } \\
\text { cost of land and } \\
\text { agglomaration } \\
\text { benefits }\end{array}$ & $\begin{array}{l}\text { Airports offer many } \\
\text { employment opportunities } \\
\text { not only directly but also } \\
\text { indirectly. }\end{array}$ \\
\hline $\begin{array}{c}\text { Augustyniak, } \\
\text { W. }\end{array}$ & 2009 & $\begin{array}{l}\text { Poland and } \\
\text { UK }\end{array}$ & $\begin{array}{c}\text { British } \\
\text { privatisation } \\
\text { model analysis }\end{array}$ & $\begin{array}{l}\text { Analysis } \\
\text { different ways } \\
\text { of airport } \\
\text { privatisation }\end{array}$ & $\begin{array}{l}\text { EBIDTA/ } \\
\text { Passengers }\end{array}$ & $\begin{array}{l}\text { Privatization needs } \\
\text { economic regulations }\end{array}$ \\
\hline Basso, L. & 2007 & UK & $\begin{array}{c}\text { Vertical relations } \\
\text { / oligopoly } \\
\text { model }\end{array}$ & $\begin{array}{l}\text { How } \\
\text { desregulation } \\
\text { may affect } \\
\text { prices? }\end{array}$ & $\begin{array}{l}\text { Airport } \\
\text { capacity/ } \\
\text { Charge per } \\
\text { flight }\end{array}$ & $\begin{array}{l}\text { "Use the airports demand } \\
\text { to obtain a measure } \\
\text { of consumer surplus } \\
\text { is incorrect if airline } \\
\text { competition is not perfect." }\end{array}$ \\
\hline $\begin{array}{l}\text { Butler, S.E. \& } \\
\text { Kiernan, L.J. }\end{array}$ & 1986 & United States & IO Tables & $\begin{array}{l}\text { Analysis the } \\
\text { economic } \\
\text { impacts of } \\
\text { airports }\end{array}$ & $\begin{array}{c}\text { Production and } \\
\text { services }\end{array}$ & $\begin{array}{l}\text { Importance of airports in } \\
\text { relation to the regional } \\
\text { economy and the } \\
\text { relevance in the creation of } \\
\text { employment. }\end{array}$ \\
\hline $\begin{array}{c}\text { Diaz, O \& } \\
\text { Ávila Álvarez, } \\
\text { J. }\end{array}$ & 2015 & Colombia & $\begin{array}{l}\text { Descriptive } \\
\text { analysis }\end{array}$ & $\begin{array}{l}\text { How airports } \\
\text { impact on the } \\
\text { economy? }\end{array}$ & \begin{tabular}{|l|} 
Contribution \\
to GPD/ \\
Creation of \\
employment/ \\
Support to \\
other industries \\
\end{tabular} & $\begin{array}{c}\text { "New policies has positively } \\
\text { affected the air transport } \\
\text { industry." }\end{array}$ \\
\hline $\begin{array}{l}\text { El-Fadel, } \\
\text { Mutasem \& } \\
\text { Chahine, M. }\end{array}$ & 2002 & Beirut & $\begin{array}{l}\text { Mathematical } \\
\text { modeling }\end{array}$ & $\begin{array}{l}\text { Economic } \\
\text { impact of noise } \\
\text { emissions }\end{array}$ & \begin{tabular}{|c|} 
using model- \\
delineated \\
noise contour \\
zones coupled \\
with population \\
and home \\
rental statistics \\
\end{tabular} & $\begin{array}{c}\text { "Social cost of noise impact } \\
\text { was evaluated at } 16.9 \\
\text { million USD per year or } \\
0.0038 \text { USD/passenger/km } \\
\text { traveled." }\end{array}$ \\
\hline $\begin{array}{l}\text { Fasone, V., } \\
\text { Giuffrè, T., \& } \\
\text { Maggiore, P. }\end{array}$ & 2012 & Italy & $\begin{array}{l}\text { Multi-airport } \\
\text { system (MAS) }\end{array}$ & $\begin{array}{l}\text { Is a a multi- } \\
\text { airport system } \\
\text { as a tool } \\
\text { for regional } \\
\text { development? }\end{array}$ & $\begin{array}{c}\text { Aircraft } \\
\text { movements/ } \\
\text { Revenues/ } \\
\text { Passengers/ } \\
\text { Investments/ }\end{array}$ & $\begin{array}{l}\text { "A well-structured multi- } \\
\text { airport system can } \\
\text { contribute significantly to } \\
\text { infrastructure management } \\
\text { and development." }\end{array}$ \\
\hline
\end{tabular}




\begin{tabular}{|c|c|c|c|c|c|c|}
\hline Forsyth, P. & 2006 & Worldwide & $\begin{array}{l}\text { Multi-approach } \\
\text { (Computable } \\
\text { general } \\
\text { equilibrium } \\
\text { models of } \\
\text { economies) }\end{array}$ & $\begin{array}{l}\text { How tourism } \\
\text { influences } \\
\text { aviation policy? }\end{array}$ & $\begin{array}{c}\text { Tourist } \\
\text { expenditure, } \\
\text { consumption, } \\
\text { profitability, } \\
\text { prices, costs, } \\
\text { demand... }\end{array}$ & $\begin{array}{l}\text { "Tourism benefits to a } \\
\text { country from aviation } \\
\text { liberalisation are not as large } \\
\text { as benefits to home country } \\
\text { travellers or the costs to } \\
\text { home country airlines." }\end{array}$ \\
\hline WTO & 1994 & Worldwide & $\begin{array}{l}\text { Cost benefits } \\
\text { opctions }\end{array}$ & $\begin{array}{l}\text { Review } \\
\text { developments } \\
\text { in aviation } \\
\text { (air transport } \\
\text { regulation) } \\
\end{array}$ & No variables & $\begin{array}{l}\text { This research offer simple } \\
\text { model to evaluate policies }\end{array}$ \\
\hline Dimitriou, D. & 2018 & $\begin{array}{c}\text { United } \\
\text { States, } \\
\text { Europe and } \\
\text { Asia } \\
\end{array}$ & $\begin{array}{l}\text { Multi-objective } \\
\text { unweighted } \\
\text { analysis }\end{array}$ & $\begin{array}{l}\text { Evaluation } \\
\text { of airports } \\
\text { productivity }\end{array}$ & $\begin{array}{l}\text { Six indicators } \\
\text { about the } \\
\text { airport } \\
\text { productivity }\end{array}$ & $\begin{array}{l}\text { Airports contribute to } \\
\text { regional development }\end{array}$ \\
\hline $\begin{array}{l}\text { Kuper, G., } \\
\text { Massacci, F., } \\
\text { Shim, W., \& } \\
\text { Williams, J. }\end{array}$ & 2020 & Hong Kong & Cost model & $\begin{array}{c}\text { Security } \\
\text { economic } \\
\text { implications } \\
\text { among airports }\end{array}$ & $\begin{array}{l}\text { Defender/ } \\
\text { Police Maker } \\
\text { and Attacker }\end{array}$ & $\begin{array}{l}\text { "Maximizing benefit } \\
\text { seeks to optimally reduce } \\
\text { risks through security } \\
\text { investment". It must be } \\
\text { a balance between the } \\
\text { investment and the future } \\
\text { risk. }\end{array}$ \\
\hline $\begin{array}{l}\text { Mense, A., \& } \\
\text { Kholodilin, K. }\end{array}$ & 2014 & Berlin & Statistic analysis & $\begin{array}{l}\text { Impacts of } \\
\text { Berlin airport } \\
\text { expansion on } \\
\text { the prices of } \\
\text { houses } \\
\end{array}$ & Housing price & $\begin{array}{l}\text { "Housing were reduced } \\
\text { substantially in the affected } \\
\text { areas by the flight path." }\end{array}$ \\
\hline $\begin{array}{l}\text { Suzuki, Y. \& } \\
\text { Crum, M. \& } \\
\text { Audino, M. }\end{array}$ & 2004 & United States & $\begin{array}{l}\text { This study } \\
\text { conducted } \\
\text { a simulation } \\
\text { experiment }\end{array}$ & $\begin{array}{c}\text { Demand } \\
\text { leakage of the } \\
\text { International } \\
\text { Airport of Des } \\
\text { Moines } \\
\end{array}$ & $\begin{array}{l}\text { Number of } \\
\text { passenger, } \\
\text { airfares, } \\
\text { benefits. }\end{array}$ & $\begin{array}{l}\text { To prevent leakage, the } \\
\text { findings included an increase } \\
\text { or decrease in airfares. }\end{array}$ \\
\hline $\begin{array}{l}\text { Oktal, H. \& } \\
\text { Küçükönal, H. } \\
\text { \& Durmaz, V. } \\
\text { \& Sarılgan, A. } \\
\text { \& Ateş, S. } \\
\end{array}$ & 2006 & Turkey & $\begin{array}{c}\text { Macro level } \\
\text { indicator analysis }\end{array}$ & $\begin{array}{l}\text { Economic } \\
\text { and socual } \\
\text { contribution of } \\
\text { air transport. }\end{array}$ & $\begin{array}{c}\text { A set of } \\
\text { indicators } \\
\text { (Passenger, } \\
\text { Cargo and GPD) }\end{array}$ & $\begin{array}{l}\text { Airports are important } \\
\text { factors in the economy }\end{array}$ \\
\hline $\begin{array}{l}\text { Takebayashi, } \\
\text { M. }\end{array}$ & 2011 & Asia & $\begin{array}{c}\text { bi-level market } \\
\text { model (Network } \\
\text { equilibrium } \\
\text { model) }\end{array}$ & $\begin{array}{l}\text { Supply/Demand } \\
\text { balance of } \\
\text { Airports in Asia }\end{array}$ & $\begin{array}{l}\text { Airfares, } \\
\text { number of } \\
\text { passengers }\end{array}$ & $\begin{array}{c}\text { "Discounting landing charges } \\
\text { increases the passenger flow } \\
\text { but diminishes the gateway } \\
\text { function for trans-Pacific } \\
\text { transport.." }\end{array}$ \\
\hline $\begin{array}{c}\text { Dimitrios, } \\
\text { D. \& } \\
\text { Mourmouris, } \\
\text { J. \& } \\
\text { Sartzetaki, M. }\end{array}$ & 2017 & Greece & I-O matrix & $\begin{array}{l}\text { Quantify the } \\
\text { impact of } \\
\text { airports }\end{array}$ & $\begin{array}{l}\text { Production } \\
\text { and services+ } \\
\text { Indicators } \\
\text { (Air carriers, } \\
\text { airports, } \\
\text { aerospace and } \\
\text { air transport } \\
\text { international } \\
\text { tourists) }\end{array}$ & $\begin{array}{c}\text { "Investment in air } \\
\text { transport infrastructure } \\
\text { will strengthen economic } \\
\text { growth, social values and } \\
\text { employment ". }\end{array}$ \\
\hline
\end{tabular}

Source: Analyzed by authors based on an academic literature review.

\section{a. The relation with the tourism industry}

Tourism is considered as a set of relations and phenomena that occur as a result of the displacement and temporary stay of people outside their place of residence, provided that it is not motivated for profit reasons (Walter Hunziker and Kart Krapf, 1942). On this matter several publications have appeared documenting that the study of impacts is positive (Ghali, 
1976; Modeste, Nelson C., 1995; Balaguer, and Cantavella, 2002 Durbaarry, 2004; Cannonier \& Burke, 2018; Chang, K.G et al., 2018; Ren T. et al.,2019).

Economic benefits are one of the main reasons why countries are interested in tourism and all it represents. In Spain, the measurement of the economic contribution of tourism to the national economies had a first approximation in 2002 by the WTO in the framework of the design of the Tourism Satellite Account (TSA). At the moment it is one of the main sources of information for the fulfillment of the analysis of tourist impact

At present, the World Travel and Tourism Council (WTTC) formed in 1991 understood that the sector's contribution to the economy and employment was not being recognized. Its objectives were to use empirical evidence to promote awareness of the economic contribution and thereby expand markets in harmony with the environment by reducing barriers to growth. In 2019, the contribution of tourism was $10.4 \%$ of world GDP. This sector created 319 million jobs; a fifth of all jobs created globally in the last five years (WTTC, 2019).

There are extensive studies related to tourism impact measures on GDP. Methodologies that include estimates based on TSA and computable general equilibrium (CGE). In the TSA, input-output tables are used and their fame has created some concern about the use of these models for measuring the impact and their multiplier effects (Archer, 1984; Fletcher \& Snee, 1989, Frechtling 1994, Dwyer, Forsyth \& Spurr, 2004). Theoretical studies are more numerous than the empirical ones, although in the last years the contribution of these is being expanded due to the interest in the subject (Var, 2002; Brida et al., 2008).

The concept of impact has a long tradition in the global analysis. It is understood as the set of effects on production, income, and employment that derive from new satisfied demand for production (González, 2010). Previous studies indicate that any event, whatever the type or category, create a great opportunity for the growth of the cities since it encourages the development of the territory and contributes to the improvement of infrastructures. (Fernández, 2014). In this sense, an airport is a fundamental axis for the sector because it is the infrastructure through which tourism, mainly international, arrives in Spain. Lian \& Denstadli (2004) stated the enormous impact of air industry for the tourism sector. According to data from the airport manager Aena (Transporte Aéreo y Turismo, 2020), 80\% of tourists arriving in our country choose the plane as a means of transport. According to Derudder B. \& Wilcox F. (2006), air transport is an important element of the economies as it provides the relationships that allow economic, social, and tourism activity.

\subsection{Measurement models}

Measuring instruments are a key element in all impact studies. To this end, the following paragraphs will describe each of the available instruments and the benefits and difficulties they present in order to be chosen as models for the economic measurement of an airport. 


\subsubsection{Quantitative measurement models}

Economic models come from the past; in fact, we can mention authors such as Walras (1834-1910), Jevons (1835-1882) or Menger (1840-1921) who attempted to explain phenomena through mathematical models. An economic model is a simplified representation of reality, a representation where variables interrelate. They offer the opportunity to explain relations between relevant economic problems such as the variables that explain the distribution of income, what is behind an economic regression ... In this model, the variables are isolated and it offers the opportunity to identify and measure the intensity of relationships by providing some reliability.

Within the economic models, we find regional econometric models. They establish relations between one or several endogenous and exogenous variables. They isolate the effect of a variable (existence of an airport) and observe how the economy operates, maintaining any other factor that affects it in a constant way. Then, we calculate the difference in the endogenous variable in the two states, with and without the existence of the airport, understanding such a difference as the causal effect of its existence. The model uses regressions to carry out macroeconomic models of regional measurement.

In the econometric models, the most used is the Input-Output. The I-O model is made through the use of the Leontief matrix, starting from the basic equation:

$$
X=A X+F
$$

Where $X$ yields the vector of the outputs of each of the activity sectors, $A$ is the internal technical coefficient matrix and $F$ the final demand. The $X$, therefore, is developed through the matrix of Leontief (I - A) -1.

The input-output models are used in the vast majority of impact studies. Its greatest advantage is the possibility of obtaining multipliers at a high level of segregation, which is very necessary if it provides results that can capture the effects of external economies (Richardson, 1986). As cited by Martín (2004) the greatest advantage of starting from a coherent and homogeneous methodological framework at the international level facilitate comparisons with other studies, as well as the scope, detail, and coherence achieved through of this methodology. Fletcher (1989) emphasizes that his method allows observing the set of cross-sectional relationships that occur within the economy and with it the direct, indirect and induced impacts divided.

The main inconvenience lies therefore in its updating and existence. As an example in relation to the latter issue, it could be found the input-output tables of the Canary Islands. In the Tenerife economic impact study, the researcher assumed that the matrix of technical coefficients of Tenerife coincides with the Canaries at the aggregate level (Gutiérrez et al., 1999). Not a few authors have come to develop methodological variants to try to overcome some limitations of this approach. These are formulations that present restrictions on the availability of resources (Wanhill, 1988); (Fleischer and Freeman, 1997) or formulations based on marginal, rather than average, relationships between variables (West and Gamage, 2001). 

del Sol

On the other hand, another econometric model is presented by the general equilibrium models. They are used concretely to construct scenarios that simulate the potential impacts on the whole of the economic system associated with certain changes. In view of the use of this model, an economic equilibrium has to be established where certain circumstances are assumed in which production, rents...etc. will converge to equilibrium. Criticism of this model emphasizes that the assumptions needed to obtain these results are extremely restrictive. These models need a clear conceptualization of the supply and demand of all the markets. We refer to structural models that tell us about market behaviors (Moniche, 2003).

The social accounting matrix model has become increasingly important over the last few years, both in estimating the impact of tourism and in the economy (Llop and Manresa, 2003). It is a representation of the most important economic relations between the agents of an economy at a moment of time. It represents the circular flow of income in a disaggregated form. Alternatively, it offers us the incorporation of all the transitions that occur between all the agents in an economy. The transactions to which we refer are operations of production, distribution, use of revenues and accumulation.

As the main advantage, it is worth highlighting the extension of the relations of the input-output model, since it is able to describe the flows between value-added and final demand representing the circular flow of income (Cardenete and Moniche, 2001). This model, when used in conjunction with linear general equilibrium models, allows for simulations with variations, for example, different aviation fiscal policies or airport public investment policies. To measure the economic impact of an airport, the social accounting matrix is a precise instrument and, above all, a tool with which to accommodate the segregated series of data that has been to collect if we want the result to be, saving the difficulties, as accurate as possible, but it is necessary to have previously made the matrix or use an existing one that is updated.

Impact evolution studies come to show causal relationships between variables. It is therefore important to mention the causal basis of the models available in the impact measurement. In this case would be how the existence of an airport affects the economy and tourism? First, we must affirm the existence of a logical causal relation since if not, we would be in front of nonsense.

According to Ullman (1996), the structural equations measure the set of relations between one or several independent variables and one or more dependent variables. However, we do have an overview, because they allow us to understand the difficulties that can and do arise in the process of analyzing the effect of one variable on another (García, 2011). The independent variable is what is supposed to be the cause of the phenomenon, the airport itself, the dependent variable would be the economy and tourism since it is understood that they are the factors observed by the existence of the independent.

This model presents the ability to construct latent variables: variables that are not measured directly, but they can be estimated thanks to the covariance relationship with other variables. It presents as an annoyance the obtaining of data and the control of the variables that, in the case of airports, cannot be predicted since we have to obligatorily start from one variable interfering in the other, and if both variables are from the same type. 
The cost-benefit model is a simple theoretical model that is based on determining the benefit of a project by assessing in monetary terms all the variables and observing the total cost of the project. Ritchie (1987) noted that measures of economic impact assessment are simple but require extremely difficult data to achieve. Even so, it has the advantage of developing a global view of effects on a region.

In 2010, the United Nations, among others, developed the TSA. Though it is not a model in itself, it was created as an instrument to account for mediation on tourism supply and demand. Note that this is not a measurement model but, rather an organization of the information available. It indicates, which is included or not within the tourist activity. It is a specific methodological basis with a general framework that the input-output tables, for example, do not have since they go from the general until focusing on the tourist economy, while that TSAs deal directly with tourism.

For Mascuñano (2001) the great advantage with respect to the input-output model is the significant decrease in the assumptions adopted in its elaboration and the ability to synthesize this scheme, which values the tourist economy, within the economy as a whole, by determining the Ratio on the proportion of production included in tourism in each product.

\subsection{Qualitative measurement technique}

This technique offers an understanding of the context or as Taylor and Bogdan (1984) stated, the use of qualitative methodology helps to understand, analyze and interpret what people say and think. Impact studies from a qualitative point of view are not being much explored in the academic literature. Generally, we can find studies that use this methodology for the explanation of catalytic impacts (The social and economic impacts of airports in Europe, 2004). This typology of impact refers to the influence that the airport has to help the creation of new businesses, increase tourism or improve the business quality of nearby companies. These impacts are greater than the sum of the previous ones but are much more difficult to measure (Lipovich, G, 2020).

Qualitative research despite its role in social sciences such as education, psychology or anthropology is still poorly defined and used as stated by Lee T. and Lee T. (1999). Cassell \& Symon (1994) described the difference between quantitative and qualitative analysis as "quantification versus interpretation".

Although purely qualitative studies do not have a presence in the literature about airports, appendices do exist in some impact research in relation to this typology of analysis. These focus on confirming the quantitative data and exploring only part of the study. For example, as mentioned in the report The Role of U.S. Airports in the National Economy, research typically focuses on safety and health (2015). If this classification is compared with the existing literature, it can be affirmed that in relation to airport activity, research is focused on passenger 
perception (Fodness, D. \& Murray, B., 2007), safety (de Gramatica, Massacci, Shim, Turhan \& Williams, 2016) and the environment (Van, 1969; Herndon et al., 2006). Besides, papers about air transport's emissions usually present a mixed methodology.

In this sense, the use of qualitative methodology can produce results such as those found in the survey of the companies at Gatwick Airport (Civil Aviation Aothority, 1996) in which $12 \%$ identified the airport as a key factor in their company's decision making and $27 \%$ perceived that independently of the economic data, the importance of the airport and what it generates is much greater than what is measured at the economic level. The survey carried out by the Holland International Distribution Council (2004) concluded that the presence of Schiphol Airport offers an attraction for the presence of distribution centers.

\section{THE METHODOLOGICAL PROPOSAL}

The results of this research define a model of measurement of the economic impact of the Airport of Malaga. It could be extrapolated to any other airport around the world.

\subsection{Spatial and temporal framework of the airport under study}

A complex problem is the definition of the territory. In Andalusia for example, not all the provinces have an airport so, part of the impacts is in these territories and not in the region where the airport is located. This research is focused on the Malaga-Costa del Sol Airport.

This infrastructure is located just 8 kilometers from the center of the capital of the Costa del Sol. The airport is made up of three terminals. Terminal 1 was closed to the public in 2015 due to energy-saving measures and operating costs until new economic conjunctures come to return to that space the character of the past years. Terminal 2 "Pablo Ruiz Picasso" is mainly used for aircraft flying from European countries, especially United Kingdom, Ireland and those included in the Schengen Agreement. Terminal 3 is operating at its maximum capacity offering a wide range of catering and spaces including one of the best VIP rooms in Europe. The facilities are completed by two runways, a private flight terminal and a cargo terminal of 5,700 square meters. 
Illustration 1. Málaga-Costa del Sol Airport Location

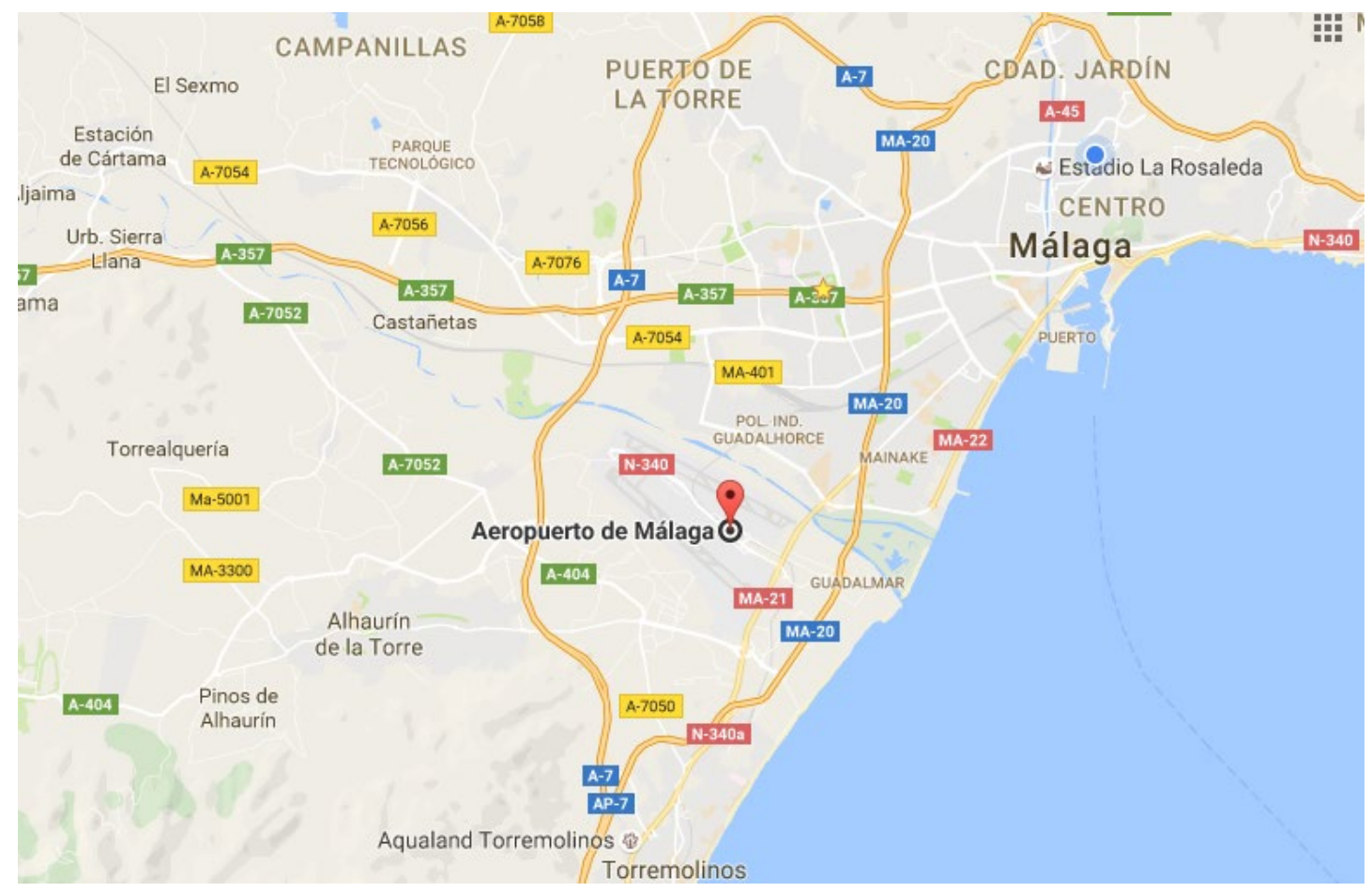

Source: $\underline{w w w . a e n a . e s}$

When we talk about the economic impact of Malaga-Costa del Sol Airport, we are referring to the territorial ambit of the province of Malaga as a tourist destination, as it is where we are going to obtain, treat and compare data. However, it should be noted that, as will be shown in the qualitative study, an airport not only affects the city in which it is located but also in the surrounding areas or even an entire country.

In addition, studies of this type would be enriched if they were carried out in different periods of time to isolate the real impact of the airport from the economic conjunctures (crisis, recession, and prosperity). It would solve countless research questions and make projections.

\subsection{Sources of information}

The data are the most important elements and the major drawback in this kind of research. The available sources of information are:

- Primary: Statistical data provided by public entities. City Council, Tourist Observatories... It is extremely important to take into account the methodology used in the collection of data, the index of significance and the date of collection as they will make the study more or less significant and, therefore, relevant.

- The secondary: publications of airport research projects both inside and outside our borders, including Measuring the Regional Economics Significance of Airports (FAA, 1986) and The Economic Impact Study Kit (ACI, 1993). 
In addition, other bibliographic sources related to the issue have been handled, such as other reports and reports from private organizations, magazines, and electronic publications, as well as other sources of key informants who have validated the object under study.

\subsection{Qualitative and quantitative paradigm}

Taking as reference the analyzed studies, we should distinguish between quantitative and qualitative impacts. Using one approach or another depends primarily on the objectives and scope of the research, but if we are to be rigorous, we will analyze both ways.

Traditionally, defenders and detractors have been clearly differentiated from both methods. Campell and Stanley (1966) and Riecken (1974) are firm supporters of quantitative methods, and Weiss and Rein (1972), Parlett and Hamilton (1976) and Guba (1978) gather around qualitative methods.

The choice of the method is crucial, and the researcher has to be realistic with the available information although sometimes the economy, the time and the availability play against. That is why we come to review the generality of these studies, starting with the choice of methods of analysis. This deliberation should not be determined by adherence to an arbitrary paradigm. And this is so because a research problem should not be linked to a series of methods, will depend on the objective to be achieved, i.e. the characteristics of what is pursued will define the choice of method. A researcher need not blindly adhere to one of the "qualitative" and "quantitative" paradigms, he must freely choose what best meets the conditions for the study (Reichardt and Cook, 1986).

However, the main problem of the quantitative approach is to objectify by giving values to data that are fully subjective. At this point, Guba (1978) points out that naturalistic research offers "a more appropriate and more sensitive mode of evaluation than anyone practice $d$ today." For example, when asked about the intention to come back to Malaga, their attitudes, opinions, preferences ... Nevertheless, it is extremely difficult to find a fully qualitative analysis of impact in relation to airports and those who have a section dedicated to it, are scarce and ancient. Our proposal is to combine the two methods to measure impact.

Observance of how and where data is taken reflects another key point. Thus, validity refers to the degree to which the study shows the research problem, while reliability refers to the consistency of the set of measurements. If we get employment data but we do not know what was the methodology used for the collection, we will start from low statistical reliability. If we add to this that the rest of the data obtained have followed a similar process, we will start from a double error. Therefore, a valid and reliable final study is of obvious necessity. The lower the level of significance, the stronger the evidence that a fact is not due to mere coincidence.

Regarding our model, although saving the differences with others previously done (Butler and Kienan, 1986), we will begin by differentiating to operational effects the quantitative impacts as all those derived directly or indirectly from the airport activity and those that are induced by the previous ones. Qualitative impacts are those that without being fully quantifiable offer us a vision about the impact indicating its effect in different sectors of Malaga. 


\subsection{Choice of economic impacts of the Airport of Málaga-Costa del Sol}

\subsubsection{Quantitative impacts}

The broadmindedness makes us be rigorous with the selected method, this has led to properly appreciate the interpretation of the reality. Therefore, observing the real is complex if a properly organized research technique is not available. Following the present methodology, the quantitative impacts are going to be divided into direct, indirect and induced (Fletcher, J.E. (1989). Although we continue with this classification, we have tried to complete and dismiss data that analytically did not fit our objectives.

\subsubsection{Direct impacts}

This kind of impact reflects the set of economic and tourist activities that are carried out as a result of its daily activity. What Garcia et al. (2003) understand as the three types of direct impact that are usually evaluated in the empirical studies: production, income and employment. At this point, we would like to add investments and taxes.

In essence, direct impacts are the consequence of the activity that occurs due to the existence of the airport, so it should not contain those jobs, incomes and effects on production that would continue to exist even if there was no airport. Segregating the aforementioned is arduous, but otherwise, we start from a direct impact of greater onset than it really does. We propose the evaluation of the activities that are developed thanks to the existence of the airport or according to its direct activity. In this sense, all the elements mentioned above have a presence or are located at the airport or within the airport area. Only those items of their business that are related to the activity of this infrastructure will be taken into account. These include:

Table 3. Elements involved in the calculation of direct impacts

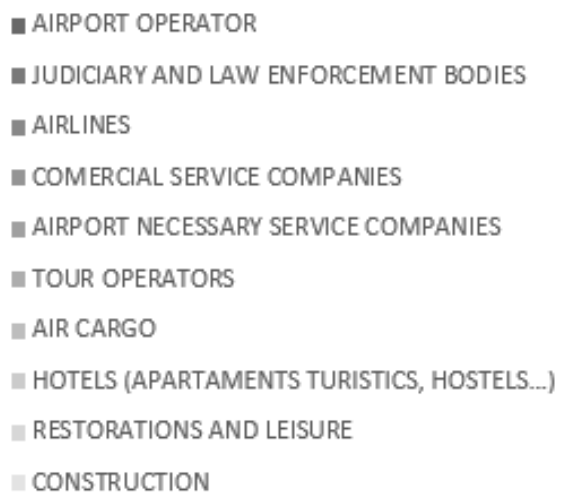

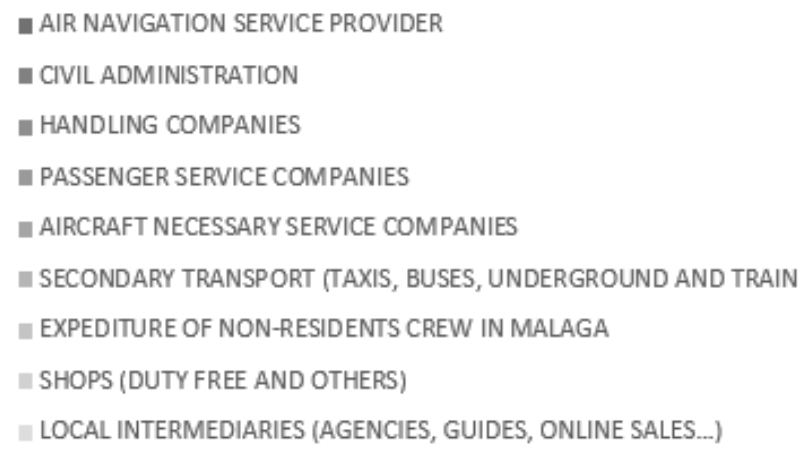

Authors.

According to the classification proposed by García et al. (1996) and introducing local taxes and investments we have to obtain the data in relation to the previous list. As far as investments are concerned, we refer to those that the airport makes directly in the city. For 
example, in this period of confinement, the airport has made an investment in technology by acquiring equipment from a local company. For the accounting information of the airport it belongs to the investment account as well as it could be the investment to adapt the access to the airport site when this infrastructure was used by the former First Lady of the United States Michelle Obama.

Table 4. Information needed for the assessment

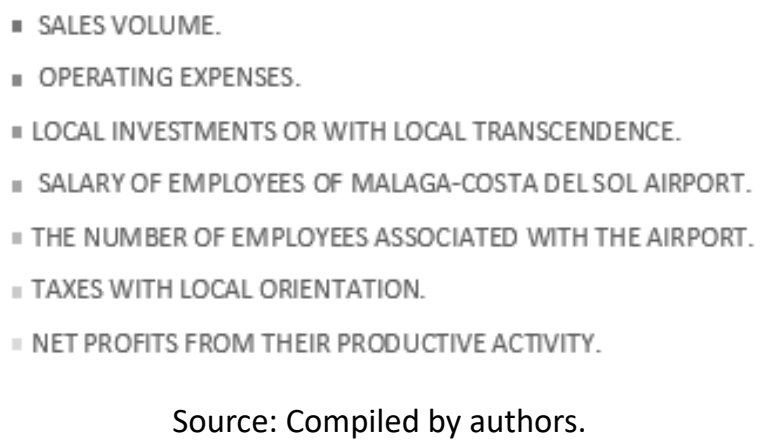

Source: Compiled by authors.

The methodology would be a survey of open and closed questions. To test if they are reliable it is necessary to test the information with the Mercantile Registry and the one from Internal Commerce, which, in the case under study, is offered by Junta de Andalucía through the Tourism and Sports Concierge.

With regard to the number of employees, only those linked to the Malaga-Costa del Sol Airport will be included. The investments must be those made in the province. The taxes will be those contemplated for reasons of rules or provisions in the territorial demarcation of the province of Malaga.

Most of this effect has repercussions in sectors such as catering, hospitality, commerce, and transport (Robusté and Clavera, 1997), to which we add the construction sector by the multiplier that is so high. Of this nothing is mentioned in previous articles and it is evident that it is a referent in Spain. Proof of its value is that the economic crisis experienced was due to the housing bubble. In this sense, an airport is vital as long as it brings passengers who can purchase their homes in the province. For this purpose, the purchase of housing by non-residents (foreign or domestic) for the year in question will be independently studied.

In order to solve the problem of the segregation of tourists we propose several sources that, in any case, will approach estimated conclusions due to the difficulty in obtaining them.

- Surveys on the residence of the passenger, who have stayed in Malaga or have visited other cities.

- Petitions from airlines on the nationality of the ticket, transit flights or stopover.

- Data provided by the Tourist Office of the Junta de Andalucía and the City of Málaga. Since 2008 Malaga has the Tourist Observatory that provides the profile of its visitors, motivations, organization of their travels, expectations... Although for their report they 
use data from other institutions is interesting the information they collect at street level from tourists in various points of the city.

The next matrix of double entry would gather all the information that we propose.

Table 5. Direct impact distribution

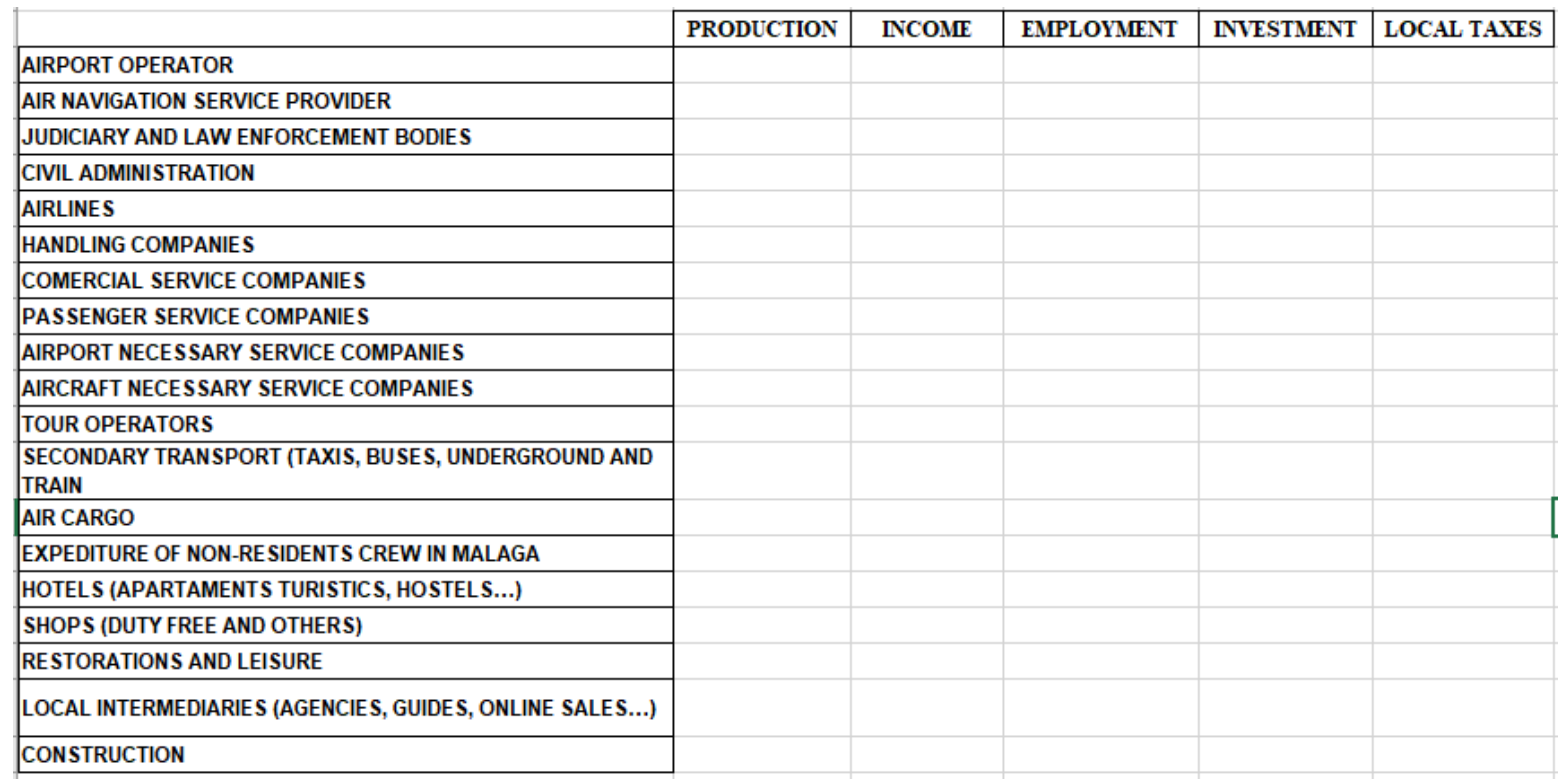

Authors.

After this, we will compare the data of production, income, employment, investment and local taxes for the total of the province obtaining the percentage that represents the aerodrome. The data of the province and Andalusia are accessible through sources such as the Bank of Spain, NSI, the Ministry of Industry, Energy and Tourism or the City Council of Malaga, among others. The result would allow verifying if an increase of the direct impact employment or investments has repercussion in the indirect impacts, hotel occupancy, rents ...etc.

\subsubsection{Indirect impacts}

The indirect effects will be obtained once the exogenous impulse, exposed in the previous section, in the selected model has been applied and will be deducted from the total after discounting the direct effects. That is, the final results on production and employment will be assessed in the case of the input-output analysis, and the considered direct effects will be detracted. As we will see later, if to carry out this analysis we apply a matrix of social accounting we will be able to observe not only the effects on the production and the employment but also on the income and the allocation of the same in the diverse institutional sectors and productive factors. 


\subsubsection{Induced impacts}

The induced impacts will reflect the effects produced on the economy as a whole and tourism in the geographical area of the province of Malaga, taking into account the multiplier effect of the direct and indirect impacts and the attributes analyzed in them. Imagine a tourist who arrives, rents a car, pays a hotel, visits a museum, eats in a restaurant, buys a souvenir ... and the next day takes a taxi to return to the airport. The company staff, the airport, the rent a car, the receptionist, and the guide, among others, assume an expense in the form of rent which in turn will be consumed in other goods and services and that will lead in its same or different sectors to a new rent for others. This circle or chain is what is called the multiplier effect of income and it is what measures the induced impact.

\subsubsection{Qualitative impacts}

Practical obstacles are likely to emerge when qualitatively assessing an impact study. Qualitative research works with people, describes their experiences, feelings, perceptions, and attempts to understand individual and collective experiences in certain circumstances and temporal spaces. This aspect is the one we use for impact studies. It will be carried out through semi-structured and in-depth interviews with experts from various sectors, airport workers, passengers, and residents.

The proposal is based on a matrix model of double entry in which the opinions are expressed with respect to the economy, the quality of life, the benefits for the territory and the environmental. The objective is to reproduce critical ideas about the perspective of the incidence of the airport from the residents' point of view. It is very important to know the space in which to focus the research activity since it is demanded of places in which the collection of information through interviews is comfortable and plausible.

To ensure the suitability and relevance of this model, a pilot study must be carried out. Tourists, residents and public and private institutions should be invited to answer the questionnaire. The study would focus on demonstrating that qualitative studies can provide very relevant information. Data that can be used for the urban planning of the airport, environmental studies, creation of new routes and/or tourist products...etc.

The questionnaire should answer the following questions:

1. What negative or positive impacts are perceived by tourists?

2. What negative or positive impacts are perceived by residents?

3. What positive or negative impacts are perceived by the city's institutions and companies?

4. What are the categories in which the types of impacts can be classified?

5. Do the residents perceive that their jobs depend on the existence of the airport?

6. Have improved the airport the residents' quality of life?

7. Despite the negative effects resulting from the research, do residents, tourists, companies and institutions estimate that these impacts are compensated by the positive ones? 
8. Do the results of the research coincide with previous research found in the literature?

9. What do they think the airport should be improved to obtain greater economic benefit?

10. Do participants perceive that the impact is decentralized to other provinces?

\section{DISCUSSION \& CONCLUSIONS}

In many countries, airports become the main route of entry for tourists. However, the state of art reveals a different fact. The majority of the studies are related to environmental impact and those related to the economic impact take into account the "aviation" and not the airport in itself. The analysis suggested by Appold (2015) highlights the economic impact that airports have in relation to employment. This is contrasted with a much earlier analysis offered by Butler and Kiernan in 1986. Privatization is a very relevant issue especially in countries like Spain where airports are managed through public companies. Some debates have arisen about the cost and benefit of these infrastructures and the need for almost all Spanish cities to have an airport. As mentioned throughout the study, in Andalusia, the Autonomous Community to which Malaga belongs, there are five airports. However, Malaga airport is the one with the most traffic and passengers. Future researchers could focus their analysis on the impact that the airport has on nearby cities. In many cases the impacts of the airport are related to tourism. This type of research usually focuses on analyzing how many tourists arrive and based on that, describing the impact of the airport for a city. Other research leads us to evaluate the economic impact of the implementation of tourism policies.

Despite being an impact study, the objective is different, i.e., as indicated in the Forsyth study (2006), tourism benefits from policies carried out in the field of aviation. And we are not only talking about an airport benefiting tourism in itself, the economic impact on the rise or fall of housing prices (Mense A. \& Kholodilin, K, 2014) are of interest in order to assess, for example, whether a house is devalued by the negative impacts generated by an airport despite its economic profitability. The passenger is another topic that acquires importance in the academic literature. The disadvantage is that knowing the number of passengers is a concrete data that without other support can lead us to unsure conclusions. In other words, Hartsfield-Jackson Atlanta International Airport is the largest airline hub in the world. In 2019 it had a total of 110,531,300 passengers; however, Atlanta receives about 50 million passengers. This means that a study of tourist spending taking into account total passengers cannot provide accurate data on the relationship between tourism and air activity in that city; further research is needed. In the field of passengers, many studies do not differentiate among types of passage. For example, does not generate the same impact the passenger who makes transit to the one who takes a bus in the same airport and goes to another city or that who spends the night. With all this, and depending on the idiosyncrasy of the study, they leave losing small impacts that added to other lost impact could represent a relevant aspect for tourist and economic purposes.

In this sense, this article tries to cover two deficiencies. On one side, it values the importance of airports for all economic, tourist and social sectors. On the other hand, this paper provides a model that can be used in all economic impact of airports. It should be borne 

del Sol

in mind that in order to compare impact studies, they must have the same methodology. In the same way as when comparing impacts in different periods. The latter is very important since if we take the examples in table 2 of the literature, we could not compare the impact of those airports (United Stated and Asia) because they do not use the same methodology. The studies provided by Takebayshi M. (2011) and Suzuki et al. (2004) observe the same variables such as airfares and passenger numbers but they focus on offering an analysis of aspects as different as the demand leakage and the discounts in landing fees.

Moreover, apart from certain reports at the European level, the degree of segregation of information results from a difficulty such that there are many estimates rather than specific data. An example of this is the case of data referring to "transport". At the Malaga-Costa del Sol Airport there is a bus service called "Aeropuerto" that runs the Airport-Downtown line. This is a direct impact but is there any research that reaches this level of segregation? If the airport does not exist, this line with complete safety, then we must not emphasize the importance of the segregation of the effects produced by the airport with differentiation of the effects produced by tourism itself. It is not a question of measuring the effects of all tourism but only of the one that arrives through the airport.

For example, at Madrid Barajas airport the indirect impact has only taken into account employment, income and GDP associated with external companies (Anon n.d.). In the impact study of Vitoria-Gasteiz Airport (Fernández et al. n.d.), they tried to calculate economic magnitudes such as the amount of wages and salaries of staff, as well as the other operating costs of each activity. Taxes of local significance, for example, are not included in the study. This means that they cannot be compared because there is no common methodology.

We consider that the most suitable model for the study of the economic impact is the matrix of social accounting. It broadens the ways of the input-output models and at the same time allows a very wide level of segregation that is fundamental. However, despite this, there are several deficiencies that go through the determination of the tourist ratio, lack of information on some activities that are not regulated or contemplated, treatment of companies and self-employed but above all the inadequacy of the goals of the TSA survey, the main axis of an impact work like this one. The models present several deficiencies that in some cases go from the generality of the attributes used to the impossibility or lack of updating of the collected data and sources. Sometimes data from public sources do not provide a methodology and if the airport is managed by a private company it is very difficult to obtain disaggregated data.

In relation to the methods, the input-output analysis is widely contemplated in almost the majority of the studies consulted. There is no better model than the one that is valid for the objectives that we pursue so that in the first term we have to mark our objective and from this point of view the model that transports us not only to a viable result but to a reliable result. Along with the previous and not less remarkable results the updating of the data. To do this is not exempt from a laborious work but without a doubt and after reviewing the studies carried out, using input-output tables from years long before the process of creating work may not be entirely successful. Recall that a model is as proper or improper as the information it uses. 
In addition, we must not forget the need for close collaboration between companies and institutions, public and private, in the need of numerous sources of information both primary and secondary. For the realization of this article, a thorough investigation has been carried out to ensure that all sources of information, both primary and secondary, are available to carry out the practical realization of this model. In this sense, researchers must work in this line and bet on becoming an engine of economic and social development through a permanent cooperation regime, surpassing that ancestral conception that the University and Society walk in separate paths. Finally, we must insist on the need to continue to deepen airports research that capture the singularities of the sector and adopt relevant impact measurement models.

In conclusion, it is relevant to add that a study at the qualitative level is necessary. The data that can be provided by the use of surveys can become a key element in airport policy planning and destination decisions. The resident as opposed to the tourist is a very little studied element and although we analyze economically the impact of an airport and we obtain great figures they may not be sufficient in relation to the environmental or social damage for a territory and its population. This is why the measurement model not only chooses the social accounting matrix with its nuances but also advocates including a deep analysis of the perceptions of the main stakeholders. Making a mixed research model can lead us to the conclusion that while a quantitative economic model must take into account the production of a region, the qualitative model can provide non-borders impacts. This means that in the case of Malaga the impacts at a qualitative level can go beyond the territory. According to data from the Institute of Statistics and Cartography $(2020), 87.5 \%(1,563,060)$ of those who visited the city of Malaga were tourists, however, in that same period the airport received 2.7 million tourists. This indicates that if we analyze the impact of the airport on tourism, it would be necessary to see which city this leak is going to. These data could be provided by this model in the part dedicated to qualitative research.

Based on the above, this paper can agree that there are no studies that quantify the impact of airports in a global way. Most focus on valuing employment and the economy without paying attention to the social aspect. The number of articles in relation to the environment means that future studies should include this aspect as well as the vision of the residents. With regard to the purely economic study, there is no standardisation, so in the case of Spain, and more specifically in relation to Máaga airport, it is not appropriate to make comparisons and therefore, decision-making between airports is not recommended if they do not present studies that contemplate the same measurement model and the same variables. 


\section{BIBLIOGRAPHY}

Akehurst, C., 1999. The impact of large airports on public health. Weekly releases (1997-2007), $3(40)$.

Alpes, M. (2015). Airport Casualties: Non-Admission and Return Risks at Times of Internalized/ Externalized Border Controls. SocialSciences, 4(3), 742-757. doi: 10.3390/socsci4030742

Analistas Económicos de Andalucía (2006). El Aeropuerto de Málaga, motor de desarrollo económico de Andalucía. Cuadernos II Plan Estratégico de Málaga. Fundación Ciedes, Málaga.

Anon. n.d. "El Impacto Económico de Un Aeropuerto." Retrieved April 6, 2020 (https://www. eadic.com/el-impacto-economico-de-un-aeropuerto/).

Appold, S., 2015. Airport cities and metropolitan labor markets: an extension and response to Cidell. Journal of Economic Geography, 15(6), pp.1145-1168.

Archer, B.H. (1984). Economic impact: Misleading multiplier. Annals of Tourism Research, 11(3), 517-518.

Augustyniak, W. (2009). Impact of Privatization on Airport Performance: Analysis of Polish and British Airports. JOURNAL OF INTERNATIONAL STUDIES, 2(1), 59-65. doi: 10.14254/2071-8330.2008/2-1/6.

Aviation and Tourism Policies: Balancing the Benefits | World Tourism Organization. (1994). Retrieved 7 July 2020, from https://www.e-unwto.org/doi/ book/10.18111/9789284400416

Balaguer, J. \& Cantavella-Jorda, M. (2002). Tourism as a long run economic growth factor: the Spanish case. Applied Economics, 34, 877-884.

Basso, L. (2007). Airport Deregulation: Effects on Pricing and Capacity. SSRN Electronic Journal. doi: $10.2139 /$ ssrn.849584

Bogicevic, V., Bujisic, M., Bilgihan, A., Yang, W., \& Cobanoglu, C. (2017). The impact of traveler-focused airport technology on traveler satisfaction. Technological Forecasting and Social Change, 123, 351-361. doi: 10.1016/j.techfore.2017.03.038

Brida, J.G., Pereyra, J.S., Devesa, M.J.S. \& Aguirre, S. Z. (2008). La contribución del turismo al crecimiento económico. Cuadernos de turismo, (22), 35-46.

Butler, S.E. \& Kiernan, L.J. (1986). Measuring the regional economic significance of airports. Office of Airport Planning and Programming, Federal Aviation Administration, U.S. Department of Transportation. Report №. DOT/FAA/PP/87-1. Washington.

Campbell, D.T. \& Stanley, J.C. (1966). Experimental and quasi-experimental designs for research. Rand McNally, Chicago

Cannonier, C., \& Burke, M. (2018). The economic growth impact of tourism in Small Island Developing States-evidence from the Caribbean. Tourism Economics, 25(1), 85-108. doi: $10.1177 / 1354816618792792$

Canter, L., \& Wood, C. (1996). Environmental Impact Assessment Review. Environmental Impact Assessment Review, 23(5), iii. https://doi.org/10.1016/s0195-9255(03)00127-6

Cardenete, M.A. \& Moniche, L. (2001): El nuevo marco input-ouput y la SAM de Andalucía para 1995. Cuadernos de Ciencias Económicas y Empresariales, 41(2), 13-31. 
Chang, K.G.; Chien, H.; Cheng, H.; Chen, H.-I. The Impacts of Tourism Development in Rural Indigenous Destinations: An Investigation of the Local Residents' Perception Using Choice Modeling. Sustainability 2018, 10, 4766.

Chaouk, M., Pagliari, D., \& Moxon, R. (2020). The impact of national macro-environment exogenous variables on airport efficiency. Journal of Air Transport Management, 82, 101740. doi: 10.1016/j.jairtraman.2019.101740

Constitución Española (1979). Retrieved 2 April 2020, from http://www.congreso.es/portal/ page/portal/Congreso/Congreso/Hist_Normas/Norm/const_espa_texto_ingles_0.pdf.

Cook, T., \& Reichardt, C. (2005). Métodos cualitativos y cuantitativos en investigación evaluativa. Madrid: Ediciones Morata.

Crandall, L., Ritchie, J.B. \& Goeldner, C.R. (1987). The social impact of tourism on developing regions and its measurement. Travel, tourism, and hospitality research. A handbook for managers and researchers, 373-383.

Cruz Ruiz, Elena \& Romero de la Cruz, Elena \& Calderón Vázquez, Francisco J. (2019). Sustainable Tourism and Residents' Perception towards the Brand: The Case of Malaga (Spain) †. Sustainability. 11. 10.3390/su11010292.

Datatur: Subdirección General de Conocimiento y Estudios Turísticos (2015) [online]. Available at: www.iet.tourspain.es [Access 7 September 2016].

de Gramatica, M., Massacci, F., Shim, W., Turhan, U., \& Williams, J. (2016). Agency Problems and Airport Security: Quantitative and Qualitative Evidence on the Impact of Security Training. Risk Analysis, 37(2), 372-395. doi: 10.1111/risa.12607

Derudder B., Wilcox F. The Geographies of Air Transport. In Global Cities and Air Transport; Goetz, A.R., Budd, L.,Eds.; Routledge: London, UK, 2016.

Diaz Olariaga, O., \& Ávila Álvarez, J. (2015). Evolution of the airport and air transport industry in Colombia and it's impact on the economy. Journal Of Airline And Airport Management, 5(1). doi: 10.3926/jairm.43

Dimitrios, Dimitriou \& Mourmouris, John \& Sartzetaki, Maria. (2017). Quantification of the air transport industry socio-economic impact on regions heavily depended on tourism. Transportation Research Procedia. 25. 5242-5254. 10.1016/j.trpro.2018.02.051.

Dimitriou, D., 2018. Comparative evaluation of airports productivity towards tourism development. Cogent Business \& Management, 5(1).

Doerr, L., Dorn, F., Gaebler, S., \& Potrafke, N. (2020). How new airport infrastructure promotes tourism: evidence from a synthetic control approach in German regions. Regional Studies, 1-11. doi: 10.1080/00343404.2020.1714022

Durbarry, R. (2004). Tourism and economic growth: the case of Mauritius. Tourism Economics, 10(4), 389-401.

Dutch Distribution Center. (2004). Retrieved 14 July 2020, from https://hollandinternationaldistributioncouncil.com/en/topics/european-distribution-centers/

Dwyer, L., Forsyth, P. \& Spurr, R. (2004). Evaluating tourism's economic effects: new and old approaches. Tourism management, 25(3), 307-317.

El-Fadel, M., \& Chahine, M. (2002). Case History: An assessment of the economic impact of airport noise emissions near Beirut International Airport. Noise Control Engineering Journal, 50(1), 30. doi: 10.3397/1.2839674 
El-Fadel, M., \& Chahine, M. (2002). Case History: An assessment of the economic impact of airport noise emissions near Beirut International Airport. Noise Control Engineering Journal, 50(1), 30. doi: 10.3397/1.2839674

Enaire.es. (2016) [online]. Disponible en: http://www.enaire.es [Access 23 March 2020].

Europe, A.C.I. (1993). The economic impact study kit. Documento de trabajo, Airports Council International.

Exceltur (2020). Valoración turística empresarial de 2019 y perspectivas para 2020. [online]. Available at: https://www.exceltur.org/wp-content/uploads/2020/01/InformePerspectivas-N71-Balance-del-an\%CC\%830-2019-y-previsiones-para-2020.pdf [Access 22 March 2020].

FAA (Cancelled) - Report No. DOT/FAA/PP/87-1 Measuring the Regional Economic Significance of Airports - Document Information. Faa.gov. (1986). Retrieved 13 July 2020, from https://www.faa.gov/regulations_policies/advisory_circulars/index.cfm/go/document.information/documentID/22732.

Fasone, V., Giuffrè, T., \& Maggiore, P. (2012). Multi-Airport System as a Way of Sustainability for Airport Development: Evidence from an Italian Case Study. Procedia - Social And Behavioral Sciences, 53, 96-105. doi: 10.1016/j.sbspro.2012.09.863

Fernández, F. Javier, Macho Xabier, Galarraga Aldanondo, Pilar González, Casimiro Parmeeta, and Bhogal Sohanpal. n.d. Evolución E Impacto Socio-Económico Del Aeropuerto De Vitoria-Gasteiz.

Fernández, M.T. (2014). El impacto turístico de los eventos deportivos: un estudio de caso. Cuadernos de turismo, 33, 59-76.

Fernández, P.S., Barandela, J.S., Rodríguez, A.R. \& Alonso, A.B. (2016). Impacto económico del XXI Campeonato de España Open de Invierno Master de Natación de Pontevedra 2015. SPORT TK-Revista EuroAmericana de Ciencias del Deporte, 169-180.

Fleischer, A. \& Freeman, D. (1997). Multiregional input-output analysis. Annals of Tourism Research, 24(4), 998-1001.

Fletcher, J. \& Snee, H. (1989). Tourism multiplier effects. En Witt, S.F. y Moutinho, L. (Eds.), Tourism Marketing and Management Handbook (529-531). Prentice Hall International. Hemel Hempstead, England.

Fletcher, J.E. (1989). Input-Output Analysis and Tourism Impact Studies. Annals of Tourism Research, 16, 514-529.

Fletcher, J.E. 1989. "Input-output analysis and tourism impact studies". Annals of Tourism Research16(4): 514-529.

Florido-Benítez, L. (2016). The impact of mobile marketing in airport. Journal Of Airline And Airport Management, 6(1), 1. doi: 10.3926/jairm.39

Fodness, D. and Murray, B. (2007), «Passengers) expectations of airport service quality», Journal of Services Marketing, Vol. 21 No. 7, pp. 492-506. https://doi. org/10.1108/08876040710824852

Forsyth, P., 2006. Martin Kunz Memorial Lecture. Tourism benefits and aviation policy. Journal of Air Transport Management, 12(1), pp.3-13.

Frechtling, D.C. (1994). Assessing the economic impacts of travel and tourism-Introduction to travel economic impact estimation. Cap. 31. En Travel, Tourism and Hospitality Research, John Wiley and Sons (2- Ed.). 
Freestone, R., 2009. Planning, Sustainability and Airport-Led Urban Development. International Planning Studies, 14(2), pp.161-176.

García Lizana, A.; Martín Reyes, G. \& Otero Moreno J.M. (1996). El impacto de los aeropuertos sobre el desarrollo económico. Civitas, Madrid.

García, J. \& Pérez, F. (1996). Metodología y medición del impacto económico de los aeropuertos: el caso del Aeropuerto de Valencia. Civitas, Madrid.

Ghali, M.A. (1976). Tourism and economic growth: an empirical study. Economic Development and Cultural Change, 24(3), 527-538.

González, M. (2010). Impacto económico de los hoteles: aplicación en la ciudad de Sevilla. Pasos: Revista de turismo y patrimonio cultural, 8(2), 319-338.

Gratton, G., Padhra, A., Rapsomanikis, S., \& Williams, P. (2020). The impacts of climate change on Greek airports. Climatic Change. doi: 10.1007/s10584-019-02634-z

Guba, E.G. (1978). Toward a Methodology of Naturalistic Inquiry in Educational Evaluation. Monografía 8a. Los Angeles: UCLA Center for the Study of Evaluation.

Gutiérrez, P., López, L.J. \& Navarro, M. (1999). Impacto económico de los aeropuertos de Tenerife en su entorno. Civitas, Madrid.

Instituto de Estadística y Cartografía de Andalucía. (2020). Retrieved 14 July 2020, from https://www.juntadeandalucia.es/institutodeestadisticaycartografia/badea/informe/ datosaldia?CodOper=b3 271\&idNode=9801\#9803

Halpern, N. (2012). Use of social media by airports. Journal Of Airline And Airport Management, 2(2). doi: 10.3926/jairm.9

Hanlon, J., 1995. Aviation and tourism policies: Balancing the benefits. Tourism Management, 16(7), pp.551-553.

Heng, T., \& Low, L. (1990). Economic impact of tourism in Singapore. Annals Of Tourism Research, 17(2), 246-269. doi: 10.1016/0160-7383(90)90086-7.

Herndon, S., Rogers, T., Dunlea, E., Jayne, J., Miake-Lye, R., \& Knighton, B. (2006). Hydrocarbon Emissions from In-Use Commercial Aircraft during Airport Operations. Environmental Science \& Technology, 40(14), 4406-4413. doi: 10.1021/es051209l

Huag, J. (2014). Climate Change and Agriculture: Impact and Adaptation. Journal Of Integrative Agriculture, 13(4), 657-659. https://doi.org/10.1016/s2095-3119(14)60752-8

Hunziker, W. \& Krapf, K. (1942). Grundriss der allgemeinen Fremdenverkehrslehre. Universidad de Berna, Suiza.

INE (2020). Estadística de movimientos turísticos en frontera. Frontur. [online] Available at: https://www.ine.es/dyngs/INEbase/es/operacion.htm?c=Estadistica_C\&cid=1254736176996\&menu=ultiDatos\&idp=1254735576863 [Access 20 March 2020].

J.Torija, A., 2018. Airport Noise Modelling For Strategic Environmental Impact Assessment Of Aviation. Science Trends,.

Jevons, S. (1879). The theory of political economy. Preface (2a Ed.). McMillan, Londres.

Kidokoro, Y., \& Zhang, A. (2017). Forms of Airport Regulation and Privatization: Effects on Airport Charge, Capacity and Welfare. SSRN Electronic Journal. doi: 10.2139/ssrn.3029683

Kuper, G., Massacci, F., Shim, W., \& Williams, J. (2020). Who Should Pay for Interdependent Risk? Policy Implications for Security Interdependence Among Airports. Risk Analysis. doi: 10.1111/risa.13454 
Lee, T., \& Lee, T. (1999). Using Qualitative Methods in Organizational Research. Sage.

Leontief, W.W. (1951). The structure of American economy, 1919-1939: an empirical application of equilibrium analysis. Oxford University Press, Nueva York.

Li, L. and Loo, B., 2016. Impact analysis of airport infrastructure within a sustainability framework: Case studies on Hong Kong International Airport. International Journal of Sustainable Transportation, 10(9), pp.781-793.

Lian,J. \& Denstadli,J. Norwegian business air travel-segments and trends. J. Air Transp. Manag. 2004,10,109-118,doi:10.1016/j.jairtraman.2003.08.001

Liesner, T., Jones, K., \& Smith, A. (1971). The Economic Impact of Commonwealth Immigration. The Economic Journal, 81(322), 425. https://doi.org/10.2307/2230109

Lipovich, G. (2014). Desmitificando algunas implicancias del transporte aéreo como herramienta de desarrollo. Voces en el Fenix. Retrieved 14 July 2020, from https:// www.vocesenelfenix.com/content/desmitificando-algunas-implicancias-del-transporte-a\%C3\%A9reo-como-herramienta-de-desarrollo

Llop, M. \& Manresa, A. (2003). Análisis de multiplicadores lineales en una economía regional abierta. Papeles de trabajo, Serie de Economía E/2003/21. Centro de Estudios Andaluces, Sevilla.

Maeda, M. (1991). The Kansai International Airport project and environmental impact assessment. Marine Pollution Bulletin, 23, 349-353. doi: 10.1016/0025-326x(91)90699-s

Martín, R.H. (2004). Impacto económico del turismo. El papel de las importaciones como fugas del modelo. Información Comercial Española, ICE: Revista de Economía, (817), 23-34.

Mascuñano, J.P. (2001). De las tablas Imput-Output a las Cuentas Satélite de Turismo en España. Estudios turísticos (148), 105-134.

Menger, C. (1950). Principles of economics. Glencoe, III. Free Press, Nueva York

Mense, A., \& Kholodilin, K. (2014). Noise expectations and house prices: the reaction of property prices to an airport expansion. The Annals of Regional Science, 52(3), 763-797. doi: 10.1007/s00168-014-0609-1

Modeste, Nelson C., 1995. "The Impact of Growth in the Tourism Sector on Economic Development: The Experience of Selected Caribbean Countries," Economia Internazionale / International Economics, Camera di Commercio Industria Artigianato Agricoltura di Genova, vol. 48(3), pages 375-385.

Moncada, S. (1999). Nitric oxide: discovery and impact on clinical medicine. Journal Of The Royal Society Of Medicine, 92(4), 164-169. https://doi.org/10.1177/014107689909200402

Moniche, L. (2003). Una Matriz de Contabilidad Social: una aplicación para Andalucía. Instituto de Estadística de Andalucía, Conserjería de Economía y Hacienda, Sevilla.

Monterrubio, C., Andriotis, K., \& Rodríguez-Muñoz, G. (2020). Residents' perceptions of airport construction impacts: A negativity bias approach. Tourism Management, 77, 103983. doi: 10.1016/j.tourman.2019.103983

Morimoto, Y. (2019). Demand Leakage from a Local Small Airport to a Regional Main Airport. International Journal of Humanities, Arts And Social Sciences, 5(1), 27-35. doi: 10.20469/ ijhss.5.10005-1

Moussiopoulos, N., Sahm, P., Karatzas, K., Papalexiou, S., \& Karagiannidis, A. (1997). Assessing the impact of the New Athens airport to urban air quality with contemporary air 
pollution models. Atmospheric Environment, 31(10), 1497-1511. doi: 10.1016/ s1352-2310(96)00283-x

Neumann, A. (2015). Why closing an Airport May not Matter - The Impact of the Relocation of TXL Airport on the Bus Network of Berlin. Procedia Computer Science, 52, 896-901. doi: 10.1016/j.procs.2015.05.160

O.M.T (2008). International Recommendations for Tourism Statistics (IRTS 2008, 2.9)

Oktal, Hakan \& Küçükönal, Hatice \& Durmaz, Vildan \& Sarılgan, Ali \& Ateş, Savaş. (2006). Social and Economic Impact Of Air Transportation: General Review.

Pabedinskaitè, A., \& Akstinaitè, V. (2014). Evaluation of the Airport Service Quality. Procedia Social and Behavioral Sciences, 110, 398-409. doi: 10.1016/j.sbspro.2013.12.884

Park, J., \& Ryu, Y. (2019). Investigating the Effects of Airport Servicescape on Airport Users' Behavioral Intentions: A Case Study of Incheon International Airport Terminal 2 (T2). Sustainability, 11(15), 4171. doi: 10.3390/su11154171

Parlett, M. \& Hamilton, D. (1976). Evaluation as illumination: A new approach to the study of program evaluation. Evaluation studies review annual, 1, 140-157.

Perlmutter, L. (1987). Regional Economic Impact of Stapleton International Airport and Future Airport Development. Regional Task Force on the Economic Impact of Stapleton Airport, Denver, Colorado. 1987. 12p. Journal Of Travel Research, 26(1), 40-40. doi: $10.1177 / 004728758702600133$

Pitfield, D. (1981). The economics of airport impact. Transportation Planning And Technology, 7(1), 21-31. doi: 10.1080/03081068108717202

Presentación - Aeropuerto de Sevilla - Aena.es. Aena.es. (2020). Retrieved 13 July 2020, from http://www.aena.es/es/aeropuerto-sevilla/presentacion.html.

Presentación - Aeropuerto F.G.L. Granada-Jaén - Aena.es. Aena.es. (2020). Retrieved 13 July 2020, from http://www.aena.es/es/aeropuerto-federico-garcia-lorca-granada-jaen/ presentacion.html.

Qin, P., \& Tian, Y. (2019). Commercialization and Privatization in the Melbourne Airport. World Journal Of Social Science Research, 6(2), 137. doi: 10.22158/wjssr.v6n2p137

Reichardt, C.S. \& Cook, T.D. (1986). Métodos cualitativos y cuantitativos en investigación evaluativa. Ediciones Morata, Madrid

Ren, J., Cao, X., \& Liu, J. (2018). Impact of atmospheric particulate matter pollutants to IAQ of airport terminal buildings: A first field study at Tianjin Airport, China. Atmospheric Environment, 179, 222-226. doi: 10.1016/j.atmosenv.2018.02.019

Ren, T.; Can, M.; Paramati, S.R.; Fang, J.; Wu, W. The Impact of Tourism Quality on Economic Development and Environment: Evidence from Mediterranean Countries. Sustainability 2019, 11, 2296.

Richardson, H.W. (1986). Economía regional y urbana. Alianza Editorial, Madrid

Riecken, H.W. \& Borouch, R.F. (1974). Social Experimentation: A Method for Planning and Evaluation Social Intervention. Academic Press, Nueva Yok

Robbins, D., \& Thompson, K. (2007). Special Issue on Transport at Tourist Destinations. Journal of Transport Geography, 15(2), 80-82. doi: 10.1016/j.jtrangeo.2006.12.001

Robusté, F. \& Clavera, J. (1997). Impacto económico del aeropuerto de Barcelona. Civitas, Madrid 
Rowe, A., \& Pitfield, D. (2018). The challenge facing existing airport campaign groups when incorporating social media into their campaign: A social network analysis of Airport Watch's social media utilisation. Geoforum, 96, 236-247. doi: 10.1016/j.geoforum.2018.08.022

Sahrir, S., Bachok, S., \& Osman, M. (2014). Environmental and Health Impacts of Airport Infrastructure Upgrading: Kuala Lumpur International Airport 2. Procedia - Social and Behavioral Sciences, 153, 520-530. doi: 10.1016/j.sbspro.2014.10.085

Shankin Alexandrovich, D. (2017). К ВОПРОСУ ОПРЕДЕЛЕНИЯ И ОЦЕНКИ ПОКАЗАТЕЛЕЙ ЭКОНОМИЧЕСКОЙ БЕЗОПАСНОСТИ АЭРОПОРТА. Article in The Conference Proceedings Of The St. Petersburg State University Of Economics, 254-257. Retrieved 2 April 2020, from https://www.elibrary.ru/item.asp?id=32691749.

Survey reports | UK Civil Aviation Authority. (1996). Retrieved 14 July 2020, from https:// www.caa.co.uk/Data-and-analysis/UK-aviation-market/Consumer-research/ Departing-passenger-survey/Survey-reports/

Suzuki, Yoshinori \& Crum, Michael \& Audino, Michael. (2004). Airport leakage and airline pricing strategy in single-airport regions. Transportation Research Part E: Logistics and Transportation Review. 40. 19-37. 10.1016/S1366-5545(03)00055-3.

Symon, G., \& Cassell, C. (1994). Qualitative organizational research. Michigan: Sage.

Takebayashi, M., 2011. Evaluation of Asian Airports as Gateways: Application of Network Equilibrium Model. Pacific Economic Review, 16(1), pp.64-82.

Taylor S.J. ; R. Bodgan (1984). "La observación participante en el campo". Introducción a los métodos cualitativos de investigación. La búsqueda de significados. Barcelona: Paidós Ibérica.

Tezel, M., Sari, D., Erdol, M., Hamamci, S. and Ozkurt, N., 2019. Evaluation of some health impact indices in two airports' domain. Applied Acoustics, 149, pp.99-107.

The Role of U.S. Airports in the National Economy. (2015). Retrieved 14 July 2020, from http:// onlinepubs.trb.org/Onlinepubs/acrp/acrp rpt 132_Appendix4.pdf

The social and economic impacts of airports in Europe. (2004). Retrieved 14 July 2020, from http://temis.documentation.developpement-durable.gouv.fr/docs/Temis/0017/ Temis-0017789/12209.pdf

Tosun, C., 2002. Host perceptions of impacts. Annals of Tourism Research, 29(1), pp.231-253.

Transporte aéreo y turismo - Aena.es. Aena.es. (2020). Retrieved 13 July 2020, from http:// www.aena.es/es/corporativa/transporte-aereo-y-turismo.html.

Turner, R. \& Freiermuth, E. (2016). Travel \& Tourism Economic Impact 2016. [online].

Ullman, J.B. (1996). Structural equation modeling (In: Using Multivariate Statistics, Third Edition, B.G. Tabachnick and L.S Fidell, Eds.).HarperCollins College Publishers. New York, NY. 709-819.

UN (United Nations) WTTC (The World Travel \& Tourism Council) (2008). Recomendaciones internacionales para estadísticas del turismo 2008. Naciones Unidas y OMT, Nueva York y Madrid.

UN, OCDE, WTTC y UE Commission 2001 Cuenta Satélite de Turismo: Recomendaciones sobre el Marco Conceptual, 2008. Estudios de Métodos, Serie F N80/Rev1. ONU, OMT, Eurostat y OECD: Luxemburgo, Madrid, Nueva York y Paris.

Van, T. (1969). Quantitative and qualitative changes in habitat and avifauna at Sydney airport. CSIRO Wildlife Research, 14(2), 117. doi: 10.1071/cwr9690117 
VAR, T. (2002). Measuring the Economic Impact of Tourism. Tourism Economics, 8(3), 261-262. Walras, L. (2013). Elements of pure economics. Routledge, Londres

Walters, A.A. (1978). Airports: an economic survey. Journal of Transport Economics and Policy, 125-160.

Wanhill, S.R. (1988). Tourism multipliers under capacity constraints. Service Industries Journal, 8(2), 136-142.

Weiss, R.S. \& Rein, M. (1972). Evaluating action programs: Readings in social action and education. Allyn and Bacon, Boston

West, G. \& Gamage, A. (2001). Macro effects of tourism in Victoria, Australia: A nonlinear input-output approach. Journal of travel research, 40(1), 101-109.

Wilke, S., Majumdar, A., \& Ochieng, W. (2015). The impact of airport characteristics on airport surface accidents and incidents. Journal Of Safety Research, 53, 63-75. doi: 10.1016/j. jsr.2015.03.006

WTTC (2019). Travel \& Tourism Economic Impact 2019 World. [online] Available at: https:// wttc.org/Research/Economic-Impact [Access 22 March 2020].

Zheng, X., Peng, W., \& Hu, M. (2020). Airport noise and house prices: A quasi-experimental design study. Land Use Policy, 90, 104287. doi: 10.1016/j.landusepol.2019.104287

\section{Autores:}

Caballero-Galeote, Lidia y García Mestanza, Josefa

1) $C G, L$ 2) $C G L$ 3) CGL y GMJ 4) CGL y GMJ 